\title{
GIARDIASIS, HELICOBACTER PYLORI AND SERUM LEVELS OF SOME MICRONUTRIENTS
}

By

\author{
ENAS Y. ABU-SAREA ${ }^{1}$, RAGHADA R. FAROUK ${ }^{1}$, MOUSA A. M. ISMAEL ${ }^{4}$, \\ MOSTAFA S. SHEEMY ${ }^{2}$, DOAA M. AHMED ${ }^{2}$, SHAIMAA A SENOSY ${ }^{3}$, \\ AND MARWA A. GHIETH ${ }^{1}$
}

Departments of Medical Parasitology ${ }^{1}$, Microbiology ${ }^{2}$, and Public Health and Community Medicine ${ }^{3}$, Faculties of Medicine, Beni-Suef University ${ }^{1,2}$, Beni-Suef Governorate, and Cairo University ${ }^{4}$, Egypt ( ${ }^{*}$ Correspondence: marwaghieth@yahoo.com)

\section{Abstract}

Giardiasis and H. pylori in upper gastrointestinal system absorbed some vitamins and mineral occurs. This study detected the serum levels of copper, zinc, vitamins B12 \& B9 among giardiasis and/or $H$. pylori patients and compared the serum levels of these minerals and vitamins among them. A total of 95 patients suffered from acute diarrhea were subjected to questionnaire taking, stool analysis, iron/haematoxylin staining, H.pylori antigen detection and serum level detection of zinc, copper, vitamins B12 \& B9. Patients were divided into G1 (n=13) for microscopic Giardia +ve, G2 $(\mathrm{n}=40)$ H. pylori +ve, G3 $(\mathrm{n}=6)$ both Giardia \& H.pylori + ve, G4 $(\mathrm{n}=36)$ Giardia \& H. pylori -ve (control). The mean age of patients was $45.7 \pm 17$. On comparing variables among patients; residence, abdominal pain and flatulence were statistically significant $(P \leq 0.05)$. Serum levels of zinc, vitamins B12 \& B9 were within normal ranges, except copper level was higher than normal in all groups. G3 (co-infections) showed the lowest levels of zinc, vitamins B12 \& B9. None of serum levels were statistically significant on comparing the four groups. Both giardiasis and H. pylori altered levels of micronutrients but during acute infection serum levels of zinc, vitamin B12 \& B9 were still within normal ranges. Pattern of infection either chronic or acute were basic regarding micronutrients levels.

Keywords: Patients, Giardiasis, H. pylori, Copper, Zinc, Vitamins B12, \& B9.

\section{Introduction}

Zinc and copper are crucial minerals for growth and worked against free radicals (Olivers et al, 2003). Zinc plays a role to help lymphocytes secretion and antibodies formation since deficiencies will affect lymphocytes (Culha and Sangun 2007). Copper strengths the action of haemopiotic system and maintains hemoglobin and iron absorption (Celiksoz et al, 2005).

Giardiasis decreased copper (Arbabi et al, 2015) and zinc levels (Demirci et al, 2003; Zarebavani et al, 2012). Giardia colonizes the upper GIT, trophozoite adherence damage the intestinal epithelium affecting absorption (Ghieth et al, 2018), where vitamin B12 \& B9 were absorbed (Olivers et al, 2002).

Both vitamins are essential for keeping $\mathrm{CNS}$ and bone health, decreasing strokes by methylation of homocystine (Elstgeest et al, 2017; Spence. 2017). Giardiasis affected the vitamins (Askari et al, 2007; Zarebavani et al, 2012).

Helicobacter pylori is gram-negative pathogen affect acidity (Gao et al, 2020) and interfere with micronutrients digestion (Öztürk et al, 2015). H. pylori colonized the entire gastric epithelium, and has an important urease activity, that leads to the ammonia production in order to protect itself from gastric acidity (Dzierzanowska-Fangrat and Dzierzanowska, 2006). The accompanied dyspepsia and malabsorption negatively change vitamin B12 and folate levels were improved by eradication (Rasool et al, 2012).

This study was implicated with the existence of the two organisms among patients with acute diarrhea and correlated zinc, copper vitamin B12 \& B9 levels among them.

Materials and Methods

Study design: A cross sectional study was done among 95 adult patients suffering from acute diarrhea and attending Outpatients clinics, Beni-Suef University Hospitals. 
Samples collection and processing: Three stool samples were collected from all patients and divided into three parts, one for coprscopic examination using direct wet mount and formalin-ethyl acetate concentration with saline and Lugol's iodine to detect Giardia and other parasites using x $10 \&$ x 40 objectives. The second part was preserved in SAF preservative for further iron/hematoxylin staining. The last part was preserved in $-20^{\circ} \mathrm{c}$ for detection of $\mathrm{H}$. pylori antigen. All patients were subjected to blood samples and serum separation for biochemical estimation of copper and zinc levels using colorimeter by the commercial kits (copper fluid auto-Dibrom PAESA method and zinc fluid mono-reagent kits, CF25911050, ZF0100050; centronic GmbH /Germany).

Serum levels of vitamin B 12 \& B 9 were detected by human vitamin B12 ELISA kit and human folic acid ELISA kit supplied by Bioassay Technology Laboratory (Catalog Number E1544Hu \& E1509Hu; England) using ELISA. According to kits, normal levels of zinc: $46-150 \mu \mathrm{g} / \mathrm{dl}$, copper: $70-155 \mu \mathrm{g} /$ $\mathrm{dl}$, vitamin B12: 160-970pg/dl and vitamin B9: $1.5-17 \mathrm{~g} / \mathrm{ml}$

Detection of $H$. pylori antigen in stool by ELISA: Stool samples were analyzed for $H$. pylori antigen using sandwich ELISA according to manufacturer's instructions, using $\mathrm{EDI}^{\mathrm{TM}}$ Fecal $H$. pylori Antigen ELISA kit, (Epitope Diagnostic, Inc, San Diego, USA).

Statistical analysis: Data were analyzed and processed using Statistical Package for Social Science, (SPSS) software version 20. Frequency and percentage were used for qualitative data. Quantitative data were presented by $\mathrm{M} \pm \mathrm{SD}$. Comparing groups as to mean of serum levels of vitamins and minerals was done using Anova test. $P$ values of less than 0.05 were considered significant.

\section{Results}

Among 95 diarrheic patients with mean age of $45.7 \pm 17$, microscopic giardiasis and staining was detected in 19 samples (20\%), and $H$. pylori antigen was detected in 46 samples (48.4\%). According to the microscopic examination of Giardia in stool samples and yielding of ELISA for $H$. pylori antigen detection, patients were divided into four groups; G1: including patients with +ve microscopic giardiasis and -ve H. pylori antigen detection $(\mathrm{n}=13), \mathrm{G} 2:$ +ve H. pylori antigen and -ve for microscopic giardiasis $(\mathrm{n}=40), \mathrm{G3}$ : patients co-infections with giardiasis and $H$. pylori antigen $(\mathrm{n}=6), \mathrm{G} 4$ : patients free from both microscopic giardiasis and $H$. pylori antigen $(\mathrm{n}=36)$. The majority were female $(53.6 \%)$, residence in urban areas $(54.7 \%)$ and using tape water $(74.7 \%)$. The commonest symptom was flatulence (28.4\%) followed by abdominal pain and fatigue $(26.3 \% \& 23.1 \%$, respectively). On comparing frequency of variables between groups, residence, abdominal pain and flatulence were statistically significant $(P$ value $\geq 0.05$ ). By using Anova test for comparing the levels of vitamins and minerals on the four groups, none was statistically significant.

\section{Results}

The results were given in tables $(1 \& 2)$ and figure (1).

\begin{tabular}{|c|c|c|c|c|c|c|c|c|}
\hline \multicolumn{3}{|c|}{ Variables } & $\mathrm{Gl}(\mathrm{n}=13)$ & $\mathrm{G} 2(\mathrm{n}=40)$ & $\mathrm{G} 3(\mathrm{n}=6)$ & G4 $(n=36)$ & Total $n=95$ & Pvalue \\
\hline \multirow{7}{*}{ 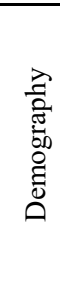 } & \multirow{2}{*}{ Sex } & Male & $5(38.5)$ & $22(55)$ & $3(50)$ & $14(38.8)$ & $44(46.3)$ & \multirow{2}{*}{0.27} \\
\hline & & Female & $8(6.51)$ & $18(45)$ & $3(50)$ & $22(61.1)$ & $51(53.6)$ & \\
\hline & \multicolumn{2}{|c|}{ Age $(\mathrm{M} \pm \mathrm{SD})$ years } & $\begin{array}{c}42.84 \pm \\
12.74 \\
\end{array}$ & $\begin{array}{c}45.23 \pm \\
16.96 \\
\end{array}$ & $\begin{array}{c}40.11 \pm \\
13.24 \\
\end{array}$ & $\begin{array}{c}43.56 \pm \\
14.22 \\
\end{array}$ & $\begin{array}{c}45.72 \pm \\
17.25 \\
\end{array}$ & 0.55 \\
\hline & \multirow{2}{*}{$\begin{array}{c}\text { Reside } \\
\text { nce }\end{array}$} & Rural & $9(69.2)$ & $15(37.5)$ & $1(16.6)$ & $18(50)$ & $43(45.2)$ & \multirow{2}{*}{$0.05^{*}$} \\
\hline & & Urban & $4(30.7)$ & $25(62.5)$ & $5(83.3)$ & $18(50)$ & $52(54.7)$ & \\
\hline & \multirow{2}{*}{$\begin{array}{r}\text { Water } \\
\text { source }\end{array}$} & tape & $10(76.9)$ & $30(75)$ & $3(50)$ & $28(3.6)$ & $71(74.7)$ & \multirow{2}{*}{0.55} \\
\hline & & filtered & $3(23)$ & $10(25)$ & $3(50)$ & $8(22.2)$ & $24(25.2)$ & \\
\hline \multirow{3}{*}{\multicolumn{2}{|c|}{$\begin{array}{l}\text { Clinical mani- } \\
\text { festation }\end{array}$}} & Fatigue & $4(30.7)$ & $7(17.5)$ & $5(83 / 3)$ & $6(16.6)$ & $22(23.1)$ & 0.06 \\
\hline & & Abdominal pain & $11(84)$ & $4(10)$ & $6(100)$ & $4(11.1)$ & $25(26.3)$ & $0.00 *$ \\
\hline & & Flatulence & $12(92.3)$ & $5(12.5)$ & $6(100)$ & $4(11.1)$ & $27(28.4)$ & $0.00^{*}$ \\
\hline
\end{tabular}


Table 2: comparing of mean laboratory values between groups

\begin{tabular}{|c|c|c|c|c|c|c|}
\hline Characteristics & $\mathrm{G} 1(\mathrm{n}=13)$ & $\mathrm{G} 2(\mathrm{n}=40)$ & $\mathrm{G} 3(\mathrm{n}=6)$ & $\mathrm{G} 4(\mathrm{n}=36)$ & Total $(\mathrm{n}=95)$ & $P$ value \\
\hline Zinc & $101.7 \pm 48.6$ & $86.9 \pm 67.7$ & $82.4 \pm 40.1$ & $137.1 \pm 219.9$ & $108.0 \pm 145.7$ & 0.508 \\
\hline Copper & $191.5 \pm 75.6$ & $234.5 \pm 168.4$ & $251.9 \pm 176.0$ & $210.0 \pm 53.8$ & $234.1 \pm 157.3$ & 0.285 \\
\hline Vitamin B12 & $570.2 \pm 668.0$ & $668.9 \pm 499.6$ & $493.98 \pm 464.0$ & $534.22 \pm 574.9$ & $512.6 \pm 53.1$ & 0.239 \\
\hline Vitamin B 9 & $3.79 \pm 2.4$ & $3.03 \pm 1.5$ & $2.347 \pm 1.2$ & $3.15 \pm 1.9$ & $3.13 \pm 1.8$ & 0.432 \\
\hline
\end{tabular}

*Mean was presented as Mean \pm SD

\section{Discussion}

In the present study, all zinc serum levels were within normal ranges $(46-150 \mu \mathrm{g} / \mathrm{dl})$, however G4 (free from both organisms) was the highest serum level $(137.1 \mu \mathrm{g} / \mathrm{dl})$, followed by G1 \& G2, $(101.7 \mu \mathrm{g} / \mathrm{dl}, 86.9 \mu \mathrm{g} / \mathrm{dl}$, respectively). Co-infections G3 was the lowest zinc level one $(82.4 \mu \mathrm{g} / \mathrm{dl})$.

Despite of Giardia infection in G1 \& $H$. pylori in $\mathrm{G} 2$, serum levels of zinc were within normal ranges. This could be a compensatory mechanism by the body following infection, where immediate depletions of body stores of zinc in acute infection (Rodríguez, 2017). Thus, it was expected that zinc deficiency during prolonged chronic infections where zinc is depleted from the body. But, co-infections of Giardia and H. pylori aggrevated lowering of zinc levels than in GI \& GII, as zinc levels were still within normal ranges, since they were not chronic. Zinc deficiency occurred in chronic giardiasis accompanied with malabsorption (Ertan et al, 2002; Culha and Sangun 2007).

In contrast, Abou-Shady et al. (2011) in Egypt showed significant lowering in zinc levels among Giardia infected patients. Others reported decrease in zinc levels and increase in copper (Olivares et al, 2003; Culha et al, 2007; Quihui et al, 2010). Difference could be attributed to dissimilarities between the studied population, nutritional deficiencies and/or disease chronicity.

As regard copper, all serum levels were much higher than normal ranges $(70-155 \mu \mathrm{g} /$ dl), but co-infections G3 was the highest $\mathrm{Cu}$ level $(251.9 \mu \mathrm{g} / \mathrm{dl})$, followed by G2, G4, \& G1 $(234.5 \mu \mathrm{g} / \mathrm{dl}, 210 \mu \mathrm{g} / \mathrm{dl}, 191.5 \mu \mathrm{g} / \mathrm{dl}$, respectively). Copper toxicity is used by the host as a defense method against infection, and elevation of copper levels was reported following infections ( $\mathrm{Fu}$ et al, 2014; Garcia-
Santamarina and Thiele, 2015). In man, copper is pledged to ceroplasmin protein with levels correlated to its concentration (Gaetke et al, 2014), controvertible to zinc which is not stored affluently within body and levels declination occurred in chronic infections.

Elevation of copper levels occurred in all groups, which means that, it was not specific to giardiasis or H. pylori. GIV (free from giardiasis and $H$. pylori), showed elevation of cu levels, but it was not ensured if patients were free from organisms rather than Giardia and H. pylori, as some parasites and commensals were diagnosed as E. histolyica, B. hominis, E. coli and Taenia species (21.05\%, 6.3\%, 4.2\%, 4.2\%, respectively) .

In the present study, vitamin B12 \& B9, levels were within normal ranges; but coinfections G3 showed the lowest serum levels than other groups (493. 98pg/dl \& 2.34g/ $\mathrm{ml}$, respectively). Zarebavani et al. (2012) found no difference among patients with and without giardiasis and vitamins B12\& B9 serum levels. Askari et al. (2007) reported vitamin B12 deficiency and normal B9 in giardiasis.

In the present, the co-infection of giardiasis and $H$. pylori decreased vitamins levels but not below normal levels, which could be attributed to the pattern of acute diarrhea.

\section{Conclusion}

H. pylori and giardiasis were prevalent among patients with acute diarrhea. Copper, zinc, vitamins B12 \& B9 levels were within normal ranges in acute diarrhea. Co-infection markedly alternated the micronutrients levels more than other groups.

\section{Acknowledgments}

The authors expressed their thanks to the Diagnostic \& Research Unit, Parasitic Diseases, Medical Parasitology Department, Faculty of Medicine, Beni-Suef University, for 
the methodology processing.

Ethical Standards: Protocol was approved by Faculty of Medicine, Beni-Suef University Research Ethics Committee in accordance with the Helsinki declaration, 1964. Samples collection was done after informing patients with the study aim and singed permission.

Conflict of interest: The authors declared that they neither have special interest nor received funds.

\section{References}

Abou-Shady, O, El Raziky, MS, Zaki, MM, Mohamed, RK, 2011: Impact of Giardia lamblia on growth, serum levels of zinc, copper, and iron in Egyptian children. Biol. Trace Elem. Res. 140, 1:1-6.

Arbabi, M, Esmaili, N, Parastouei, K, Hooshyar, H, Rasti, S, 2015: Levels of zinc, copper, magnesium elements, and vitamin b12, in sera of schoolchildren with giardiasis and entrobiosis in Kashan, Iran, Zahedan. J. Res. Med. Sci. 17, 11: e3659-62.

Askari, F, Ghaffarifar, F, Dalimi, ASL Haghi H, Ashtiani MT, et al, 2007: Study on variation of the sera folic acid, vitamin $\mathrm{B}_{12}$ and iron level in the 6-12 years old patients infected with Giardia lamblia in south Tehran Iran. J. Pediatr. 17, 2:149-54.

Celiksoz, A, Acigoz, M, Degerli, S, Alim, A, Aygan, C, 2005: Egg positive rate of Enterobius vermicularis and Taenia spp.: By cellophane tape method in primary school children in Sivas, Turkey. Korean J. Parasitol. 43, 2:61-4

Culha, G, Sangun, MK, 2007: Serum levels of zinc, copper, iron, cobalt, magnesium and selenium elements in children diagnosed with Giardia intestinalis and Enterobiosis vermicularis in Hatay, Turkey. Biol. Trace Elem. Res. 118, 1: 21-6.

Demirci, M, Delibas, N, Altuntas, I, Oktem, F, Yönden, Z, 2003: Serum iron, zinc and copper levels and lipid peroxidation in children with chronic giardiasis. J. Hlth. Popul. Nutr. 21, 1:725.

Dzierzanowska-Fangrat, K, Dzierzanowska, D, 2006: Helicobacter pylori: microbiology and interactions with gastrointestinal microflora. J. Physiol. Pharmacol. 57, 3:S514.

Elstgeest, LEM, Brouwer, IA, Penninx, BW H, van Schoor, NM, Visser, M, 2017: Vitamin $\mathrm{B}_{12}$, homocysteine and depressive symptoms: A longitudinal study among older adults. Eur. J. Clin. Nutr. 71, 4:468-75.

Ertan, P, Yereli, K, Kurt, O, Balcioğlu, IC, Onăg, A, 2002: Serological levels of zinc, copper and iron elements among Giardia lamblia infected children in Turkey. Pediatr. Int. 44, 3: 286-8.

Fu, Y, Chang, FM, Giedroc, DP, 2014: Copper transport and trafficking at the host-bacterial pathogen interface. Acc. Chem. Res. doi: 10.1021/ ar500300n.

Gaetke, LM, Chow-Johnson, HS, Chow, CK, 2014: Copper: toxicological relevance and mechanisms. Arch. Toxicol. 88, 11:1929-38.

Gao, T, Zhao, M, Zhang, C, Wang, P, Zhou, W, et al, 2020: Association of Helicobacter pylori infection with vitamin D deficiency in infants and toddlers Am. J. Trop. Med. Hyg. 102, 3: 541-6

Garcia-Santamarina, S, Thiele, DJ, 2015: Copper at the fungal pathogen-host axis. J. Biol. Chem. 290, 31:18945-53.

Ghieth, MA, El-Badry AA, Abu-Sarea, EY, Kotb, MA, 2018: Intestinal parasitosis and pediatric hepatic disease: coproscopy and immunomolecular assays. J. Egypt. Soc. Parasitol. 48, 2: 475-80

Olivares, JL, Fernández, R, Fleta, J, Rodríguez, G, Clavel, A, 2003: Serum mineral levels in children with intestinal parasitic infection. Dig. Dis. 21, 3:258-61.

Öztürk, N, Kurt, N, Özgeriş, FB, Baygutalp, NK, Tosun, MS, et al, 2015: Serum zinc, copper, magnesium and selenium levels in children with Helicobacter pylori infection. Eurasian J. Med. 47, 2:126-9.

Quihui, L, Morales, GG, Mendez, RO, Leyva, JG, Esparza, J, et al, 2010: Could giardiasis be a risk factor for low zinc status in schoolchildren from northwestern Mexico? A cross-sectional study with longitudinal follow-up. BMC Pub. Hlth. 10, 1:85-9

Rasool, S, Abid, S, Iqbal, MP, et al, 2012: Relationship between vitamin $\mathrm{B}_{12}$, folate and homocysteine levels and $H$. pylori infection in patients with functional dyspepsia: A cross-section study. BMC Res. Notes 5:206-8.

Rodríguez, JT, 2017: Giardiasis and zinc absorption. Curr. Trop. Med. Rept. 4:153-7.

Spence, JD, 2017: Increased coagulation with aging: Importance of homocysteine and vitamin B12. Circ. J. 81, 2:268. doi: 10.1253/circj. 
Zarebavani, M, Dargahi, D, Einollahi, N, Dashti, N, Mohebali, M, et al, 2012: Serum levels of zinc, copper, vitamin B12, folate and immu- noglobulins in individuals with giardiasis. Iran J. Pub. Hlth. 41, 12:47-53.

\section{Explanation of figure}

Fig. 1 a: E. coli cyst, b: Giardia cyst, c: Giardia trophozoite, d: Giardia cyst, e: E. histolytica cyst, f: Capillaria egg (x40, a, b, e \& f: Lugol's iodine stain. c, d: iron/haematoxylin stain).

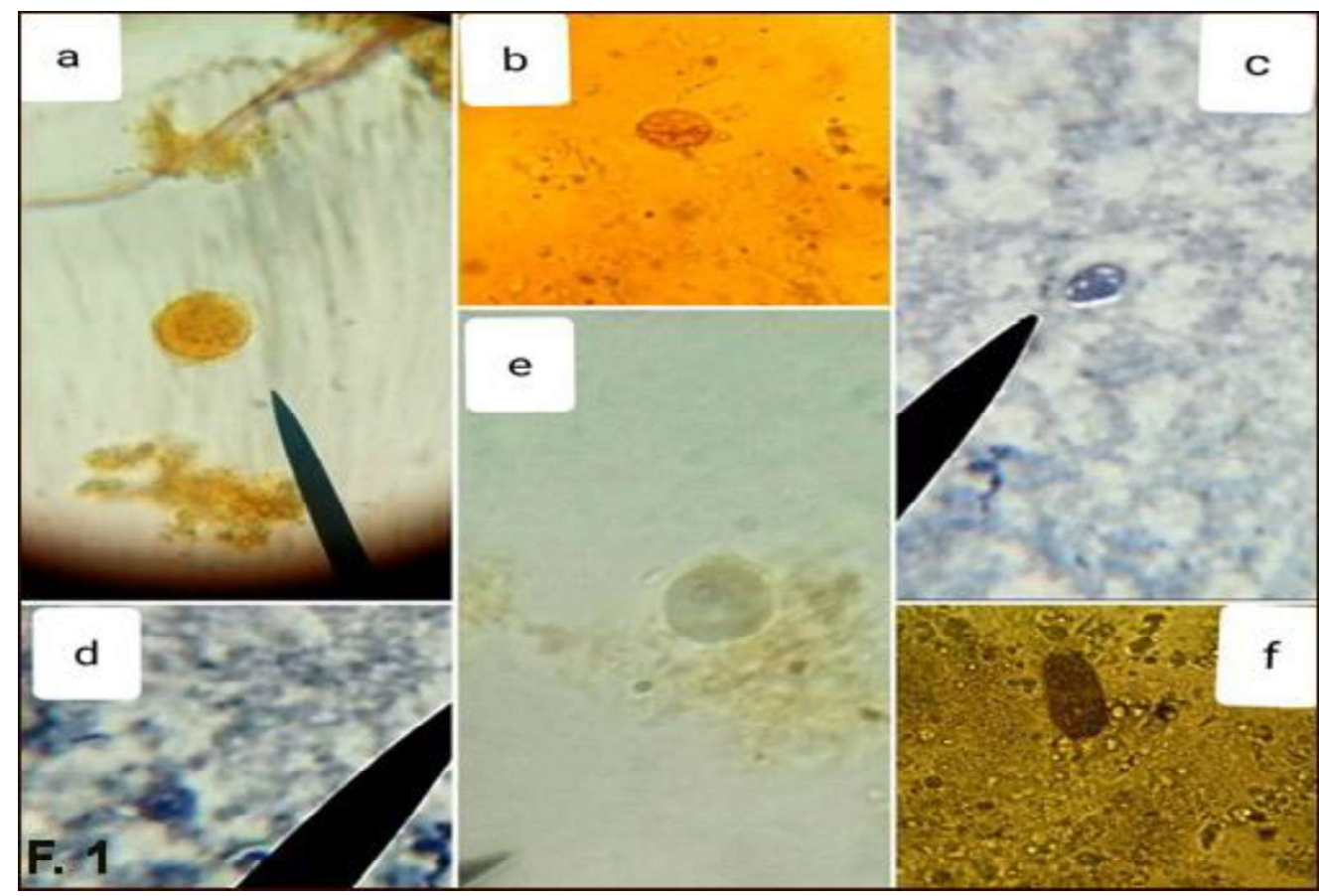

